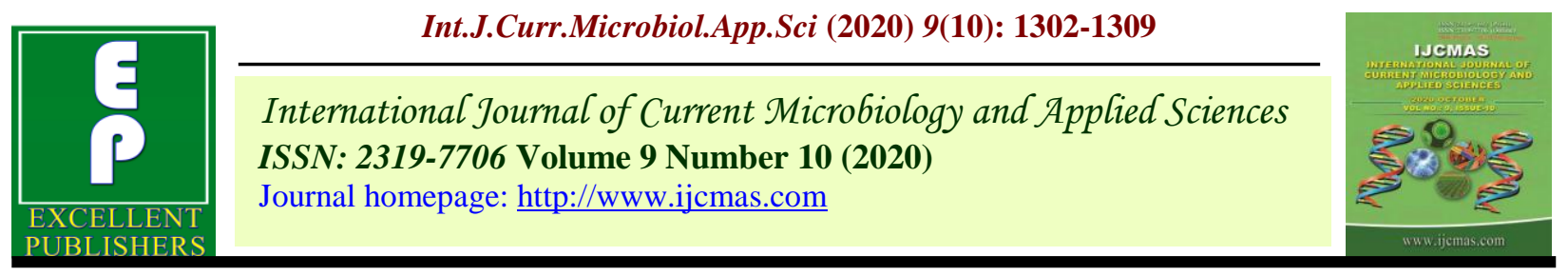

Original Research Article

https://doi.org/10.20546/ijcmas.2020.910.157

\title{
Perform Cluster Analysis to Assess the Differences for Storage Seed Protein Profile in the Cowpea Mutants
}

\author{
Madhu Choudhary ${ }^{*}$, K. Ram Krishna and Rajwanti Saran
}

Department of Plant Breeding and Genetics, S.K.N. College of Agriculture, SKN Agricultural
University, Jobner303329(Jaipur), Rajasthan, India

*Corresponding author

\section{A B S T R A C T}

\section{Keywords}

Cowpea mutants, Seed storage protein, Clustering, SDS-page

\section{Article Info}

Accepted: 12 September 2020 Available Online: 10 October 2020
An investigation was carried out on 38 mutants derived from EMS $(0.5 \%)$ mutagenesis of two cowpea varieties RC-19 and RC-101 to determine the variation in their profile of seed storage protein subunits through sodium dodecyl sulphate - polyacryl amide gel electrophoresis (SDS-PAGE).The protein bands of the 40 genotypes (parents and mutants) could be placed in five distinct regions. The protein bands of region I, II and V were monomorphic and intensely stained and identified to have a MW between $97.4 \mathrm{kD}$ to 43 $\mathrm{kD}$. Only certain bands of region III and IV were polymorphic. The binary data generated from the polymorphic bands over the genotypes were used to compute Jaccard's similarity coefficients using NTSYS-pc software. The similarity matrix thus prepared was used to construct a dendrogram by UPGMA. The dendrogram distributed the 40 genotypes in 11 clusters. About $50 \%$ mutants were in one cluster and their parents in other clusters. One mutant in each group assumed unique place i.e. mutant 30 (dd) of RC101 and mutant 37 (kk) of RC 19. Clustering seemed to be independent of the seed attributes studied. The protein content of the mutants was invariably reduced as compared to their parents and ranged from 21-30.3\%. It was concluded that results of the studies may be useful in selection of mutants for hybridization program for possible improvement of the quality of seed storage proteins in cowpea.

\section{Introduction}

Cowpea [Vigna unguiculata (L.) Walp] is an annual, self-pollinated, leguminous crop (Mackie and Smith, 1935) with a chromosome number of $2 n=2 x=22$ (Darlington and Wyile, 1955) and belongs to family Fabaceae (earlier Leguminoceae). Cowpea is native to India (Vavilov, 1949) but tropical and Central Africa is also considered as secondary centers of origin where wild races are found even now ( $\mathrm{Ng}$ and Marechal, 1985). There are several diverse uses of cowpea due to which the varietal requirement in terms of plant type, seed type, maturity, pattern of use and growth are diverse from region to region. Therefore, cowpea breeding program becomes more complex and no single variety can be suitable for all objectives (Barrett, 1987). Thus, there is need to develop varieties suitable for a specific region and use. However, production is constrained by low 
and variable grain yield, grain quality, susceptibility to diseases and pests and the absence of improved cultivars. The genetic diversity in cowpea seems to be narrow in spite of substantial variation in seed color, seed proteins, plant type, pod type and seed size among cultivated cowpeas (Panella and Gepts, 1992; Vaillancourt et al., 1993; Pannella et al.1993). For an effective breeding program, the characterization of genetic diversity for making choice of parents for hybridization is important while the seed storage protein profile, on one hand, is an important consideration to be taken in account when drawing inferences from genetic diversity studies based only on morphological traits, such a protein profile, on the other hand, directly refers to its nutritional status. The research work related to mutant characterization in cowpea using SDS-PAGE of storage seed protein is very scanty. The objective of the present investigation was therefore, to perform cluster analysis to assess the differences in the mutants of cowpea varieties RC-19 and RC-101 for this storage seed protein profile.

\section{Materials and Methods}

A total of 40 genotypes of cowpea (Vigna unguiculata) comprising 38 mutants and two of their parents RC-101 and RC-19 were evaluated in the present study. These material were obtained from the Department of Plant Breeding and Genetics, at S.K.N. College of Agriculture, Jobner. The list of mutants of cowpea and their parents along with their seed characters are presented in (Fig. 1 and Table 1). A random sample of 100 seeds was drawn from each genotype and weighed in gram (g).Seed volume of each genotype was recorded in milliliters $(\mathrm{ml})$. For protein extraction, seed coat and embryo were removed and cotyledons were ground and sieved to get o fine powder. Estimation of protein $(\%)$ of the seeds by micro Kjeldhal method described by Peach and Tracey (1956). SDS-PAGE was conducted according to procedure of Laemmli (1970) with minor modification described by Tripathy et al., (2010). Proteins were extracted by grinding first in $1.0 \mathrm{ml}$ of water followed by subsequent grinding in $1.0 \mathrm{ml} \mathrm{Nacl}$, extracted protein sample $(1.0 \mathrm{ml})$ were transferred into Eppendorf tubes and centrifuged for 3 minutes at $10,000 \mathrm{rpm}$. One half milliliter $(0.5 \mathrm{ml})$ of supernatant was transferred into a fresh Eppendorf tube (1.5ml tube) and denatured with $0.5 \mathrm{ml}$ cracking buffer $(0.2 \mathrm{M}$ Tris Hcl buffer $\mathrm{P}^{\mathrm{H}}$ 6.8, 10\% SDS, 20\% Glycerol, $10 \mathrm{~mm}$ Mercaptoethanol, $0.05 \%$ bromophenol blue) at $80^{\circ} \mathrm{C}$ in a water bath for 15 minutes. Bromophenol blue (BPB) added to the cracking buffer served as tracking dye to monitor the movements of protein bands in the gel. These samples were loaded into the wells of the polyacrylamide gel slab prepared for electrophoresis. The electrophoresis was carried out on BioRAD vertical gel electrophoresis equipment (Model: protein II Xi Cell, Fig. 2) along with a power supply. The molecular weight of the dissociated polypeptides was determining by using standard molecular weight marker obtained from Merk provided by Bengalore-Genei (Range $29 \mathrm{kD}$ to $205 \mathrm{kD}$ ).

\section{Electrophoretic equipment)}

Gels were scored for the presence (1) and absence (0) of every protein subunit band. These binary data were used to analyze using NTYSYS - pc (Numerical Taxonomy System, Version 2.1 Rohlf 2000). The SIMQUAL sub- program was used to calculate the Jaccard's coefficient using following formula (Jaccard, 1998).Jaccard's coefficient $=\mathrm{N}_{\mathrm{AB}}$ / $\left(\mathrm{N}_{\mathrm{AB}}+\mathrm{N}_{\mathrm{A}}+\mathrm{N}_{\mathrm{B}}\right)$. Similarity matrices as computed by the program were used to construct the UPGMA (un- weighted pair group method with arithmetic average (Sneath and Sokal, 1973). Dendrogram was 
constructed to elucidate the diversity among the accessions studied. Statistical stability of the branches in the cluster was estimated by bootstrap analysis with 1000 replicates, using Winboot software program (Yap and Nelson, 1996).

\section{Results and Discussion}

The present investigation employing SDSPAGE of seed storage proteins was carried out on different mutants of cowpea variety RC-101 (white seeded) and RC-19 (light brown seeded). On account of their distinct seed coat color/ seed shape/ plant type these mutants have been investigated for variations in seed storage protein profile. The protein extracts from the cotyledons of 40 genotypes (i.e. parent and 38 mutants) were prepared as described above and 14 samples loaded on a gel plate at a time along with marker protein in the first lane. The comb used in these experiments could develop 15 wells for loading the samples.

A comparison of banding pattern reveals that there are five distinct regions of proteins. The first region corresponds to $97.4 \mathrm{kD}$, second region was relatively thick and darkly stained, it reveals two subunits $43 \mathrm{kD}$, third 4 lightly stained bands followed by thick band showed $29 \mathrm{kD}$, fourth region 6 lightly stained bands each below $29 \mathrm{kD}$, and fifth region has only one prominent band. Win et al., (2011) have also described a similar picture of electrophoregram in cowpea accessions of Myanmar and have identified 5 regions on the basis of banding pattern within the similar molecular weight range of $97 \mathrm{kD}$ to $15 \mathrm{kD}$. However, on the basis of results of protein band polymorphism, the results of the present study are at variance from those of Win et al., (2011). The marker protein has invariably shown 5 distinct protein bands of 205, 97.4, 66.0, 43.0 and 29.0 kD MW. The Jaccard's similarity co-efficient between different accessions ranged between 0.2 and 1.00 with a mean of 0.54. Considerable number of genotypes showed absolute similarity. Among the 40 genotypes (38 mutants +2 parents), minimum genetic similarity (maximum diversity) value was associated with 38 cases of pairs whereas maximum similarity coefficient values were associated with 171 cases of pairs. It is also seen that $34.26 \%$ of the pairs showed similarity coefficient values within the range of 0.2 to 0.3 indicating these genotypes carry deviations from the parents or mutants.

A dendrogram was constructed using Jaccard's similarity coefficients obtained for protein band binary data observed on the 40 genotypes of cowpea employing NTSYS-pc program (Fig. 3). The cluster analysis on the accessions revealed 11 distinct clusters. The salient finding of the clustering are described as follows:

At 0.5 similarity coefficient, three clusters could be identified, namely 1, 2 and 3 . Cluster 1 included half of the mutants (mutants of both the parents). Cluster 2 included only one mutant i.e. 30 whereas in cluster 3 represented the rest of the mutants including both the parents.

At 0.7 similarity coefficient, 11 clusters could be seen. Mutant 17 was similar to RC-101 and the mutant 33 was similar to RC-19.

A comparison of the mutant's seed appearance with clusters showed no association between them. Even protein content/seed volume/100 seed weight seemed to have no relation with clustering because higher or lower magnitude for these traits were observed with the mutants in all the clusters.

Storage seed proteins seemed to be independent of seed characteristics studied. 
Table 1 Seed attributes and protein content of cowpea mutants and parents

\begin{tabular}{|c|c|c|c|c|}
\hline $\begin{array}{l}\text { S. } \\
\text { No. }\end{array}$ & Designation & $\begin{array}{c}100 \text { Seed Weight } \\
(\mathrm{gm})\end{array}$ & Seed Volume(ml) & $\begin{array}{c}\text { Seed } \\
\text { Protein(\%) }\end{array}$ \\
\hline 1 & $\mathrm{a}$ & 9.43 & 9.4 & 24.09 \\
\hline 2 & $\mathrm{~b}$ & 8.98 & 10.4 & 24.35 \\
\hline 3 & $\mathrm{c}$ & 8.18 & 8.4 & 23.32 \\
\hline 4 & d & 8.95 & 9.4 & 26.24 \\
\hline 5 & e & 6.18 & 6.4 & 22.75 \\
\hline 6 & $\mathrm{f}$ & 4.75 & 5.4 & 25.66 \\
\hline 7 & $\mathrm{~g}$ & 5.91 & 6.4 & 23.62 \\
\hline 8 & $\mathrm{~h}$ & 10.10 & 9.4 & 26.33 \\
\hline 9 & $\mathrm{i}$ & 5.96 & 6.9 & 28.99 \\
\hline 10 & $\mathrm{j}$ & 4.99 & 5.4 & 25.74 \\
\hline 11 & $\mathrm{k}$ & 5.82 & 6.4 & 21.57 \\
\hline 12 & 1 & 9.24 & 8.4 & 22.75 \\
\hline 13 & $\mathrm{~m}$ & 8.67 & 7.4 & 26.10 \\
\hline 14 & $\mathrm{n}$ & 7.45 & 6.4 & 23.18 \\
\hline 15 & o & 7.20 & 7.4 & 27.56 \\
\hline 16 & $\mathrm{p}$ & 9.54 & 9.4 & 21.93 \\
\hline 17 & $q$ & 9.91 & 9.4 & 22.70 \\
\hline 18 & $\mathrm{r}$ & 7.76 & 7.4 & 21.78 \\
\hline 19 & $\mathrm{~s}$ & 6.13 & 6.4 & 21.78 \\
\hline 20 & $\mathrm{t}$ & 10.18 & 9.4 & 24.50 \\
\hline 21 & $\mathrm{u}$ & 8.41 & 8.4 & 25.46 \\
\hline 22 & $\mathrm{~V}$ & 8.92 & 6.4 & 21.62 \\
\hline 23 & $\mathrm{w}$ & 8.12 & 7.4 & 25.19 \\
\hline 24 & $\mathrm{X}$ & 8.66 & 7.9 & 22.51 \\
\hline 25 & $\mathrm{y}$ & 4.56 & 5.4 & 28.43 \\
\hline 26 & $\mathrm{Z}$ & 7.72 & 8.4 & 24.41 \\
\hline 27 & aa & 7.44 & 8.4 & 21.81 \\
\hline 28 & $\mathrm{bb}$ & 6.22 & 5.4 & 24.10 \\
\hline 29 & $\mathrm{cc}$ & 7.32 & 7.4 & 26.56 \\
\hline 30 & Dd & 8.65 & 7.9 & 28.43 \\
\hline 31 & $\mathrm{Ee}$ & 10.09 & 10.4 & 24.94 \\
\hline 32 & $\mathrm{ff}$ & 7.69 & 7.9 & 23.42 \\
\hline 33 & gg & 7.25 & 7.4 & 21.84 \\
\hline 34 & hh & 10.06 & 10.4 & 26.25 \\
\hline 35 & ii & 8.28 & 8.4 & 26.26 \\
\hline 36 & $\mathrm{jj}$ & 7.53 & 7.9 & 21.81 \\
\hline 37 & $\mathrm{kk}$ & 7.25 & 8.6 & 24.58 \\
\hline 38 & 11 & 7.19 & 9.4 & 24.84 \\
\hline 39 & RC-19 & 7.20 & 6.4 & 29.28 \\
\hline 40 & RC-101 & 8.92 & 7.4 & 30.03 \\
\hline
\end{tabular}


Table.2 Seed attributes of mutants of cowpea variety RC-19 with cluster

\begin{tabular}{|c|c|c|c|c|}
\hline Cluster & $\begin{array}{l}\text { No. of } \\
\text { mutants }\end{array}$ & \multicolumn{3}{|l|}{ Seed attributes } \\
\cline { 2 - 5 } & $\begin{array}{l}\text { 100 Seed } \\
\text { weight } \mathbf{( g . )}\end{array}$ & $\begin{array}{l}\text { Seed volume } \\
\text { (ml.) }\end{array}$ & $\begin{array}{l}\text { Protein } \\
\text { content (\%) }\end{array}$ \\
\hline & 6 & 4.75 & 5.4 & 25.66 \\
\hline & 10 & 4.99 & 5.4 & 25.74 \\
\hline \multirow{2}{*}{ I } & 11 & 5.82 & 6.4 & 21.57 \\
\hline & 25 & 4.56 & 5.4 & 28.43 \\
\hline II & 22 & 8.92 & 6.4 & 21.62 \\
\hline III & 23 & 8.12 & 7.4 & 25.19 \\
\hline IV & 36 & 7.53 & 7.9 & 21.81 \\
\hline V & RC-19 & 7.25 & 8.6 & 24.58 \\
\hline
\end{tabular}

Fig.1 Seeds of cowpea mutants of RC-101 and RC-19; Fig.2 Bio-RAD vertical gel Electrophoretic equipment
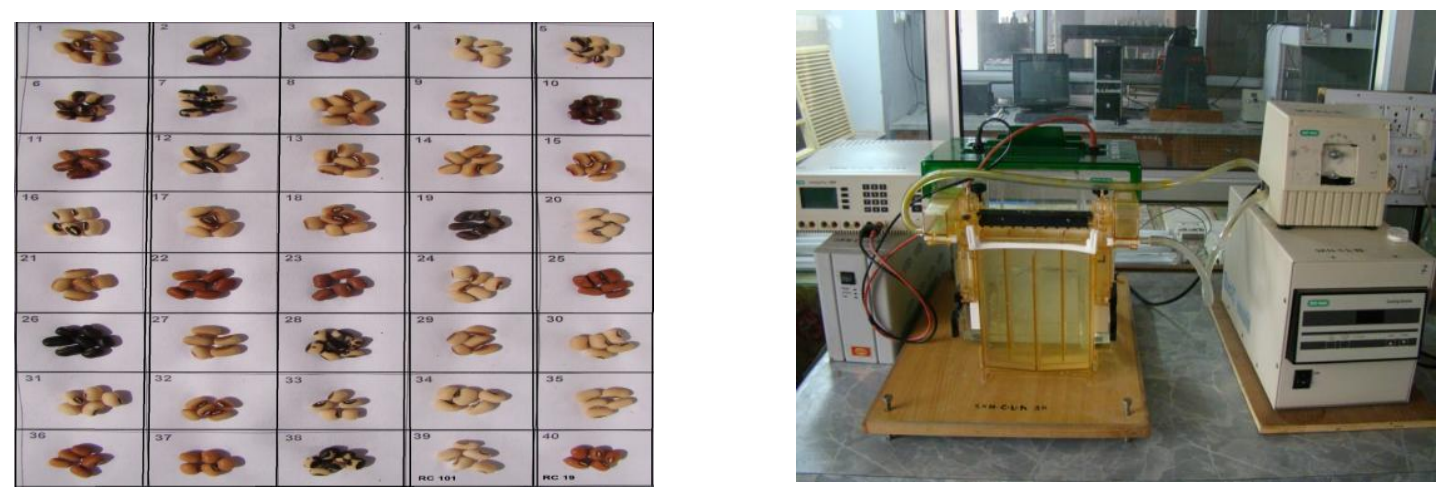

Fig.3 Dendrogram of the 38 cowpea mutants and their parents revealed by UPGMA cluster analysis of SDS-PAGE based genetic similarity estimates

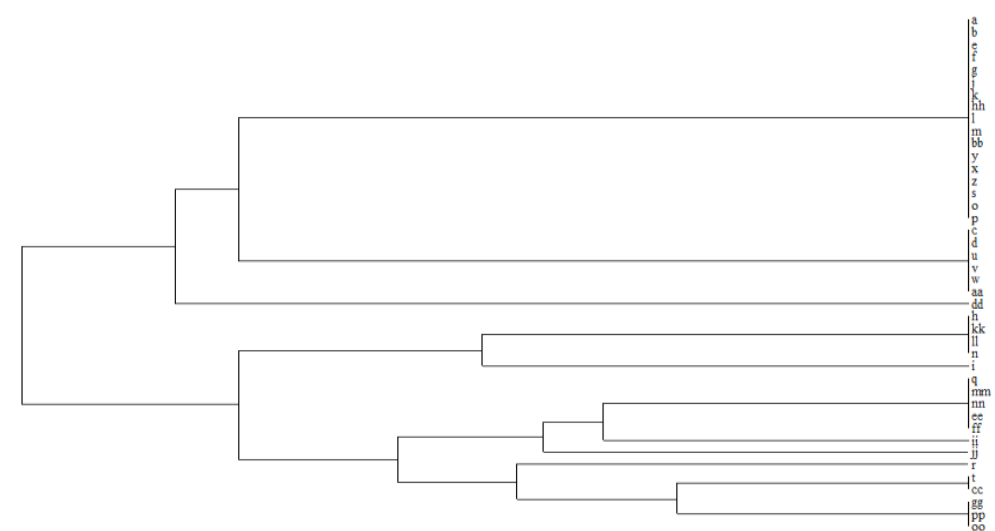

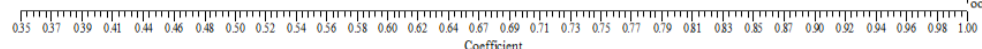


Fig.4 Dendrogram of the 8 cowpea genotypes (mutants of RC 19) revealed by UPGMA cluster analysis of SDS-PAGE based genetic similarity estimates

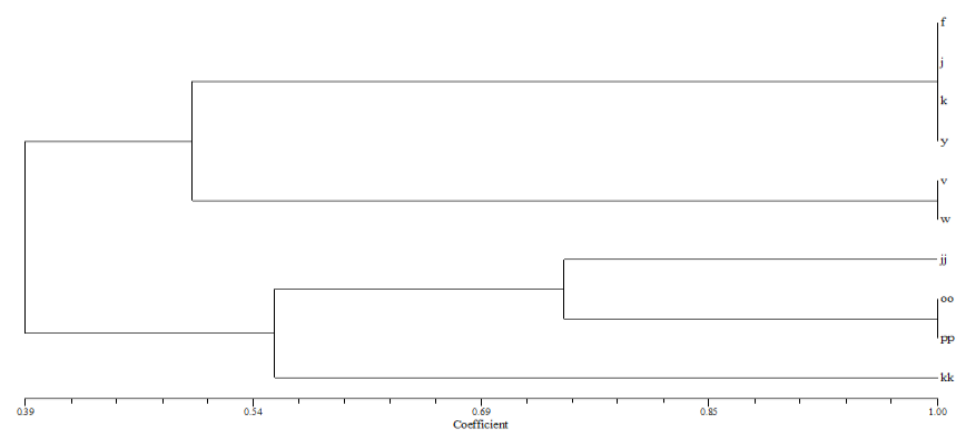

Fig.5 Dendrogram of the 30 cowpea genotypes (mutants of RC 101) revealed by UPGMA cluster analysis of SDS-PAGE based genetic similarity estimates

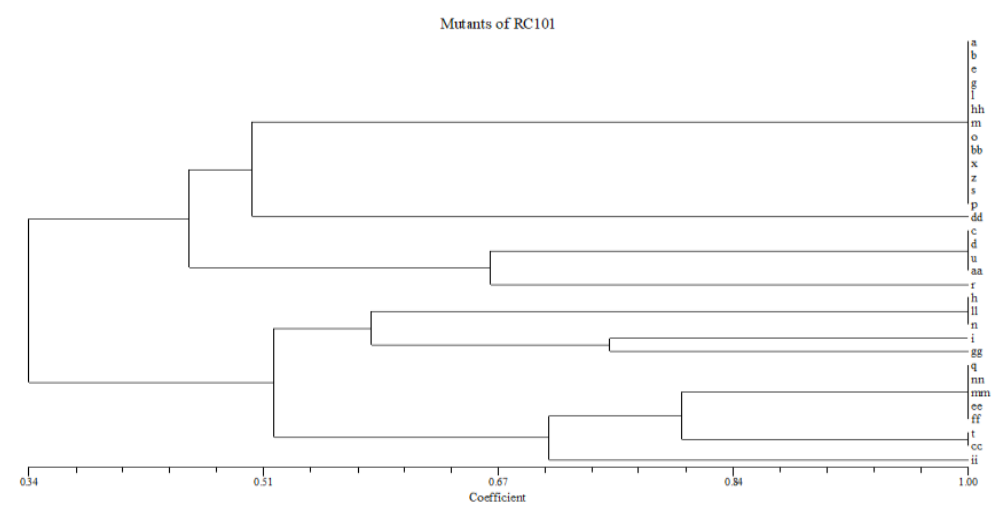

Fig.6 Protein bands identified in the mutants showing difference in the protein bands indicated by arrows, top of the lanes is mutant number 
The results thus demonstrate that the two parents are quite close to each other on the basis of seed storage protein banding pattern but about $50 \%$ of the mutants are quite distinct from the parents and similar among themselves. A separate dendrogram for mutants of RC-19 and that of RC-101 were prepared (Figs. 4 and 5). It can be seen that, in case of 8 mutants of RC- 19 studied, all the mutants fell in five clusters where as in case of 30 mutants of RC-101 ten distinct clusters were visible. In case mutants of RC-19 there seemed an association between clusters and seed attributes studied (Table 2). The results of present study have demonstrated that a large number of mutants of cowpea have deviated from their parents in the seed storage protein profile. This was substantiated by the dendrogram which revealed 5 clusters for mutants of RC-19 (Fig. 4) and 10 clusters for mutants of RC-101 (Fig. 5) which may be indicative of different loci which have been mutated. Certain mutants such as 1, 21, 22, 26, 29, 35, and 38 (Fig. 6) may give interesting results if crossed with the parents. Hameed et al., (2012) reported in the chickpea accessions studied, a mutant ILC-95 could be distinguished from the rest on the basis of three distinct polypeptides. The protein content of the mutants was invariably reduced as compared to their parents and ranged from 21-30.3\%. On account of convincing discrete mutational changes that have occurred in the mutants studied, it would be plausible to further characterize these mutants for their nutrient contents and perform hybridization between the selected ones to explore the possibility of improving the nutritional quality in the recombinants.

\section{References}

Barrett, R.P. 1987. Integrating leaf and seed production strategies for cowpea [ Vigna unguiculata (L.) Walp.]. M.S. Thesis, Michigan State University, East
Lansing. M.I. USA. 391-396.

Darlington, C.D. and Wylie, A.P. 1955. Chromosome atlas of flowering plants. George Allenand Unwin Ltd., London. 251-270.

Hammed, A., Saddiqa, A., Nadeem, S., Iqbal, V., Atta B.M., and Shah, T.M. 2012. Genotypic and mutant identification in Cicer arietinum by seed storage protein profiling. Pak. J. Bot. 44(4):1303-1310.

Jaccard, P. 1908. Nouvelles recherches sur la distribution florale. Bulletin de la Société Vaudoise des Sciences Naturelles. 44: 223-270.

Laemmli, U. K.1970. Cleavage of Structural Proteins during the Assembly of the Head of Bacteriophage T4. Nature, 227: $680-685$.

Mackie, W.W. and Smith, F.L. 1935. Evidence of field hybridization in beans. J. Am. Soci. Agro. 27: 903-908.

Ng, N.Q. and Marechal, R. 1985. Cowpea taxonomy, origin and germplasm. In: Cowpea research, production and utilization, S.R. Singh and K.O. Rachie (eds.) Wiley, New York. pp. 11-21.

Panella, L. and Gepts, P. 1992. Genetic relationships within Vigna aunguiculata (L.) Walp. based on isozyme analyses. Genet. Res. Crop Evo. 39(2): 71-88.

Panella, L., Kami, J. and Gepts, P. 1993. Vignin diversity in wild and cultivated taxa of Vigna aunguiculata L. Walp. (Fabaceae). Eco. Bot., 47: 371-386.

Peach, K. and Tracey, M.V. 1956. Modern methods of plant analysis. Vol. I Springer Verlag, Berlin.

Rohlf, F.J. 2000. NTSYS-pc: Numerical Taxonomy System. Ver. 2.1. Exeter Software, Setauket, NY, USA. 29-34.

Sneath, P.H.A. and Sokal R.R. 1973. Numerical Taxonomy. W.H. Freeman and Company, San Francisco.

Tripathy, S.K., Sardar, S.S. and Mishra, P.K. 2010. Analysis of seed storage protein 
pattern: a method for studying genetic variation and diversity among Vigna genotypes. Indian J. Genet. 70(2): 140144.

Vaillancourt, R.E., Weeden, N.F. and Barnard, J. 1993. Isozyme diversity in the cowpea species complex. Crop Sci., 33: 606-613.

Vavilov, N.I. 1949. The origin, variation, immunity and breeding of cultivated plants. Chronica Botnica, 13: 1-54.

Win, K.T., Oo, A.Z., New, K.L., Thein, M.S. and Yutaka, H. 2011. Diversity of
Myanmar cowpea accessions through seed storage polypeptides and its cross compatibility with the subgenus Ceratotropis. J. Plant Breed. Crop Sci., 3(5): 87-95.

Yap, I. V. and Nelson, R. J. 1996. WinBoot: a program for performing bootstrap analysis of binary data to determine the confidence limits of UPGMA-based dendrograms. IRRI Disc. Ser. No. 14. I.R.R.I, Manila, Philippines.

\section{How to cite this article:}

MadhuChoudhary, K. Ram Krishna and Rajwanti Saran. 2020. Perform Cluster Analysis to Assess the Differences for Storage Seed Protein Profile in the Cowpea Mutants. Int.J.Curr.Microbiol.App.Sci. 9(10): 1302-1309. doi: https://doi.org/10.20546/ijcmas.2020.910.157 